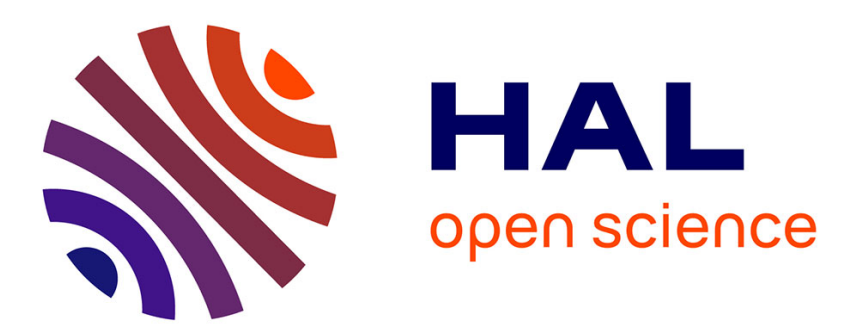

\title{
Magnetic Components Dynamic Modeling With Thermal Coupling for Circuit Simulators
}

\author{
Alaa Hilal, Marie-Ange Raulet, Christian Martin
}

\section{To cite this version:}

Alaa Hilal, Marie-Ange Raulet, Christian Martin. Magnetic Components Dynamic Modeling With Thermal Coupling for Circuit Simulators. 21st Soft Magnetic Materials Conference (SMM 21), Sep 2013, Budapest, Hungary. hal-01191335

\section{HAL Id: hal-01191335 \\ https://hal.science/hal-01191335}

Submitted on 1 Sep 2015

HAL is a multi-disciplinary open access archive for the deposit and dissemination of scientific research documents, whether they are published or not. The documents may come from teaching and research institutions in France or abroad, or from public or private research centers.
L'archive ouverte pluridisciplinaire HAL, est destinée au dépôt et à la diffusion de documents scientifiques de niveau recherche, publiés ou non, émanant des établissements d'enseignement et de recherche français ou étrangers, des laboratoires publics ou privés. 


\title{
MAGNETIC COMPONENTS DYNAMIC MODELING WITH THERMAL COUPLING FOR CIRCUIT SIMULATORS
}

\author{
A. Hilal, M.A. Raulet, C. Martin \\ Université de Lyon, Université Lyon 1, F69622, France \\ CNRS UMR5005 AMPERE, 43, Bd du 11 Novembre 1918, Villeurbanne, F69622, France
}

Virtual prototyping is essential in the development of new power electronics devices like transformers and static power converters. Circuit simulators as SPICE and SIMPLORER allow the optimization of complex circuit prototypes by associating models of passive and active components. Magnetic components constitute a major part of electronics devices, therefore accurate modeling of magnetic materials is mandatory in order to predict their realistic behavior under variable operating conditions. In fact nonlinear characteristics of magnetic materials in addition to dynamic and thermal effects have a non-negligible influence on device's performance and must be taken into account in circuit simulations [1].

This paper takes place in this context by proposing a non-linear dynamic model of magnetic components for use in circuit simulators. It includes the material's nonlinear hysteresis behavior with accurate modeling of winding and core losses in addition to thermal effects that are not taken into account by existing models. The model is based on the principle of separation of static and dynamic contributions as well as Bertotti's theory [2].

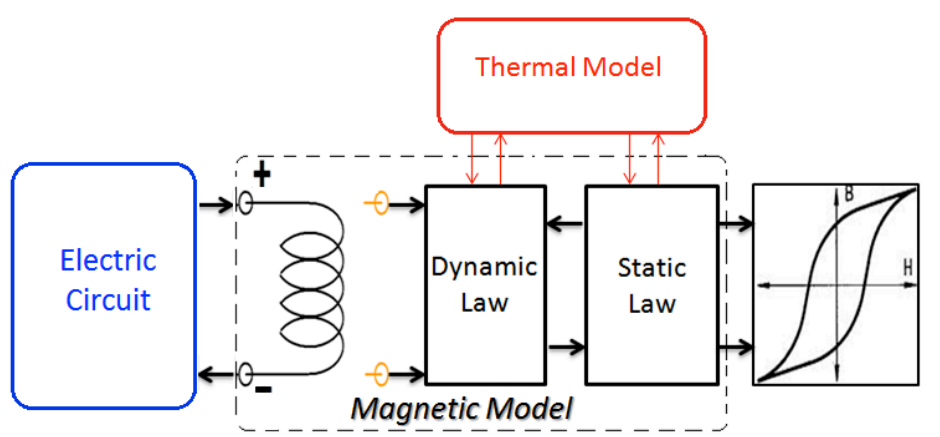

In the interest of precision and in order to be adaptable for different types of magnetic materials, the magnetic component model adopts structural modeling approach. As a consequence the model consists of 3 major blocks as shown in the adjacent figure: a winding responsible for coupling between electrical and magnetic domains using Ampere's and Faraday's laws, a static model to describe

the static hysteresis behavior of the magnetic material and a dynamic model to add classical and excess losses in the core. Each of these blocks is described using VHDL-AMS [3] modeling language due to its multi-domain modeling feature, allowing coupling with a thermal model. The thermal model can be represented by a simple temperature source for static thermal conditions or by an equivalent thermal circuit for self-heating conditions.

The magnetic component model is validated by modeling a Nanocrystalline-core inductor. The appropriate choice of static law able to describe the piecewise linear static behavior of the material is presented. The identification of static and dynamic models parameters is discussed. Thermal effects are investigated, by predicting the model's parameters variation as function of temperature. The effects of frequency and waveform are also studied.

[1] PR. Wilson, J. Neil Ross, AD. Brown, "Simulation of Magnetic Component Models in Electric Circuits Including Dynamic Thermal Effects", IEEE TRANSACTIONS ON POWER ELECTRONICS, vol.17, no. 1, January 2002.

[2] G. BERTOTTI, "General properties of power losses in soft ferromagnetic materials", IEEE Transactions on Magnetics, vol. 24, no. 1, pp. 621-630, 1988.

[3] P. ASHENDEN G. D. PETERSON, D. A. TEEGARDEN, "The System Designer's Guide to VHDLAMS", Morgan Kaufman Publishers, 2002.

Alaa HILAL:

Alaa.hilal@univ-lyon1.fr 